\title{
Remotely sensed time series of rapid terrace formation: Laguna del Viedma valley (Patagonia)
}

\author{
*Varyl R. Thorndycraft ${ }^{1}$ \\ 1 Centre for Quaternary Research, Department of Geography, School of Life Sciences and the Environment, Royal Holloway University \\ of London, Egham TW20 OEX United Kingdom. \\ Varyl.Thorndycraft@rhul.ac.uk \\ * Corresponding author: Varyl.Thorndycraft@rhul.ac.uk
}

\begin{abstract}
The Patagonian Andes were affected by a range of geophysical drivers of landscape incision during the Last Glacial Interglacial Transition and Early Holocene. Deciphering drivers of river system response during this period is complex, and magnitudes and timescales of landscape change are poorly constrained. Herein, a remotely sensed time series of modern terrace formation is investigated from the Laguna del Viedma valley as a modern analogue of Late Quaternary landscape evolution in Patagonia. The aim of the research was to constrain the timing of terrace formation following lake level fall of the Laguna del Viedma over a 35 year period from 1985-2019. The objectives were to: 1) use satellite imagery from 1985-2019 to document glacier and lake changes in the study area; 2) map landforms of the Laguna del Viedma valley; and 3) analyse terrace elevations. In total seven terrace surfaces were distinguished, with the oldest four pre-dating the ALOS PALSAR DEM (February 2000) used. Landform evidence shows the highest, and vegetated, T1 terrace surface $(+40-75 \mathrm{~m})$ grades to the highest lake level and was likely the elevation of the valley floor during Holocene neoglacials. Viedma glacier recession then led to a phase of lake regressions/transgressions with an overall trend of lake level fall. The DEM shows $\sim 20 \mathrm{~m}$ incision from the 1985 floodplain level (T3) to the T4 level floodplain by 2000. This constrains a minimum rate of incision of $1.33 \mathrm{~m} / \mathrm{yr}$, however, the satellite time series demonstrates rapid T3 terrace formation, with evidence for mass movements contributing to lateral terrace erosion by 1986. The implications of the data are discussed within the context of the Late Quaternary palaeohydrology of Patagonia where lake level falls of $10 \mathrm{~s}$ to $100 \mathrm{~s}$ of metres occurred within many large river systems of the Patagonian Andes from $42-52^{\circ} \mathrm{S}$. The data herein demonstrate that base level falls from sudden lake drainage events were likely a major driver of rapid landscape change in Patagonia during deglaciation.
\end{abstract}

Keywords: Base level, Glacial lake outburst floods, Palaeohydrology, Paraglacial geomorphology, Patagonia, Remote sensing.

RESUMEN. Series temporales de teledetección de la formación rápida de terrezas: valle de la Laguna del Viedma (Patagonia). Los Andes patagónicos fueron afectados por diversos factores geofísicos que condujeron a la incisión del paisaje durante la transición del último glaciar-interglaciar y el Holoceno temprano. La determinación de los controles en la incisión de los sistemas fluviales durante este período resulta compleja, a la vez que las magnitudes y escalas de tiempo de cambio del modelado no se encuentran suficientemente acotadas. En este trabajo se analiza la formación de terrazas modernas mediante el estudio de una serie temporal de imágenes de teledetección que sirve de análogo moderno de la evolución del paisaje durante el Cuaternario tardío en la Patagonia. En esta investigación se persigue acotar el tiempo de la formación de las terrazas en relación con el descenso de nivel de la Laguna del Viedma durante un periodo de 35 años, desde 1985 al 2019. Los objetivos específicos son los siguientes: 1. utilizar imágenes de satélites para documentar los cambios glaciares y del nivel del lago en la zona de estudio; 2. cartografiar la geomorfología del valle de la Laguna del Viedma; y 3. analizar la elevación de las terrazas. En total, se han distinguido siete terrazas, cuatro de ellas se formaron con anterioridad al modelo digital de elevación (DEM) de ALOS PALSAR (febrero 2000). Las evidencias geomorfológicas muestran que la terraza (T1), de mayor altura y vegetada ( $+40-75 \mathrm{~m})$, se inclina y enrasa con el nivel más alto del lago y, probablemente, se corresponde con el fondo del valle durante el desarrollo de los neoglaciares del holoceno. La recesión del glaciar Viedma provocó una fase de regresiones/transgresiones del lago, con una tendencia general al descenso de su nivel. El DEM muestra una incisión de $\sim 20 \mathrm{~m}$ que comprende desde el nivel de la llanura fluvial en 1985 (T3) hasta la llanura del nivel T4 formado antes del 2000. Esta observación implica 
una tasa de incisión mínima de 1,33 m/a, aunque las imágenes de satélite demuestran una formación rápida de la terraza (T3), con evidencia de movimientos de masa que contribuyeron a la erosión lateral de la terraza en 1986. Las implicaciones de estos resultados se discuten dentro del contexto paleohidrológico del Cuaternario tardío en la Patagonia donde se produjeron descensos en el nivel de los lagos del orden de decenas a centenas de metros, que afectaron el nivel de base de muchos de los grandes sistemas fluviales de los Andes patagónicos entre 42-52 ${ }^{\circ} \mathrm{S}$. Igualmente, estos datos demuestran que la caída de nivel de base causada por vaciamientos súbitos constituyeron un control primordial en los cambios rápidos de paisaje en la Patagonia durante la deglaciación.

Palabras clave: Nivel del base, Inundaciones de lagos glaciares, Paleohidrología, Geomorfología paraglacial, Patagonia, Teledetección satelital.

\section{Introduction}

Base level is a key concept in fluvial geomorphology (e.g., Davis, 1902; Schumm, 1993). As defined by Schumm (1993) base level is an imaginary level surface that limits fluvial incision. In inland settings, Faulkner et al. (2016) recognised three local to regional-scale types of base level: enclosed depressions, lake levels, or rivers downstream of tributary valleys. Base level, therefore, can be controlled by rise/fall in eustatic sea level (Schumm, 1993; Harvey, 2002), rise/fall of lake level altitude (Harvey, 2002; Bowman et al., 2010) or incision/aggradation in downstream river valleys (Faulkner et al., 2016).

Changes to lake levels and downstream riverbed elevations can be particularly dynamic during deglaciation and paraglacial response of Late Quaternary terrestrial landscapes. During deglaciation the magnitude of ice dammed lake falls in Patagonia can be in the order of 10 s to 100 s of metres (e.g., Bell, 2008; García et al., 2014; Solari et al., 2012; Turner et al., 2005; Thorndycraft et al., 2019). Rates of base level change can occur over abrupt $\left(10^{1}-10^{2} \mathrm{yr}\right)$ timescales, for example in response to changes in sediment supply (Faulkner et al., 2016), while glacial lake outburst flood (GLOF) events can cause rapid $(<1 \mathrm{yr})$, geologically instantaneous, lake level falls (Jacquet et al., 2017). Furthermore, high magnitude GLOFs can cause major erosion and channel incision along the flood pathway (Baker, 2009; O'Connor et al., 2020; Benito and Thorndycraft, 2020), lowering base level at confluences with tributaries otherwise unaffected by the flood event. The interpretation of rates of Late Quaternary landscape change can, therefore, be challenging in formerly glaciated valleys, not least given constraints on dating precision. This is especially so where there are multiple drivers, such as the Patagonian Andes where isostatic uplift (Dietrich et al., 2010), tectonics and dynamic topography (Guillaume et al., 2013; Dávila et al., 2019; Ávila and Dávila, 2019) can lead to uplift or subsidence.
In this paper, the rate of terrace formation in response to base level falls/transgressions resulting from ice dammed lake drainage/refilling is investigated using satellite remote sensing as a modern analogue for Late Quaternary landscape evolution in Patagonia. The study area is the lower Viedma glacier, an outlet glacier of the Southern Patagonia Icefield, and the ice-dammed Laguna del Viedma valley (Fig. 1). The aim of the paper is to test the hypothesis that incision up to 10 s of metres could occur over rapid (sub-decadal) timescales in response to lake level fall. The objectives are to: 1) use satellite imagery from the period 1985-2019 to document landform, glacier and lake changes in the study area; 2) use remotely sensed imagery to map landforms of the lower Viedma glacier and Laguna del Viedma valley; and 3) analyse terrace elevations from the ALOS PALSAR DEM, which uses SRTM datasets collected in February 2000. The implications of the Laguna del Viedma data are discussed with respect to the interpretation of Late Quaternary landforms resulting from deglaciation of the former Patagonian Ice Sheet.

\section{Study area}

The Viedma Glacier (Fig. 1) is one of the major outlet glaciers draining the eastern ice-shed of the Southern Patagonia Icefield. The glacier terminates in a calving ice-margin at the western end of Lago Viedma at $\sim 250 \mathrm{~m}$ a.s.l. At the southern ice margin of the lower Viedma, the ice blocks a SW-NE aligned drainage basin (Fig. 2) forming the ice-dammed Laguna del Viedma. During the local Late Glacial Maximum the Viedma ice limits extended 10s of km east of its present position (Ponce et al., 2019) so the catchment of the present day Laguna del Viedma would have been beneath thick ice at this time.

The emergence of ice-free conditions in the Laguna del Viedma valley is undated but the presence of trimlines, ice-scoured bedrock, tributary valley 
moraine complexes (Fig. 2), and dense valley forest indicate the likely extent of Holocene neoglacial advances based on moraine records elsewhere. For example, to the north of the Viedma glacier, the Torres glacier, which shows a similar valley glacier landsytem, formed moraines at $\sim 9.7,6.9,6.1,4.5$, and $0.53 \mathrm{ka}$ (Reynhout et al., 2019). The presence of an arête on the eastern catchment watershed shows the modern glaciers are now mainly disconnected from the icefield (Fig. 1).

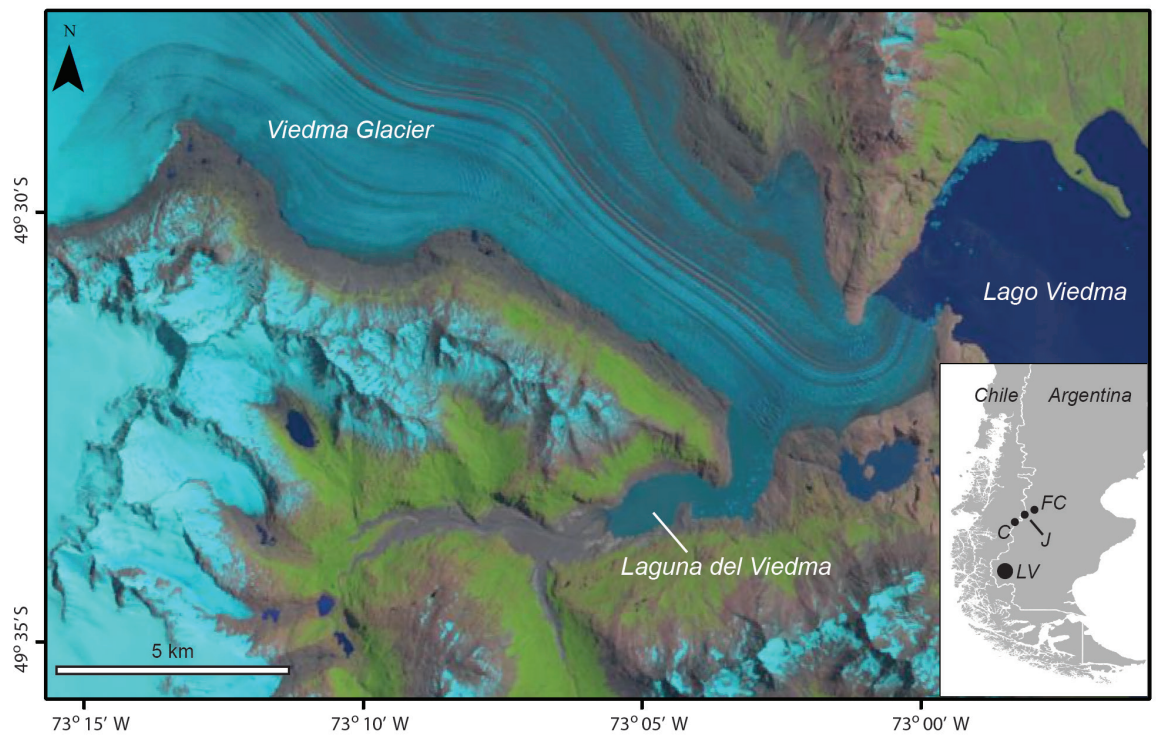

FIG. 1. Inset: Location of the Laguna del Viedma (LV) study area. Also shown are the Chacabuco (C), Jeinimeni (J) and Fénix Chico (FC) valleys presented in figure 10. Main panel: LANDSAT image (16/01/2004) showing Viedma Glacier blocking the Laguna del Viedma valley.

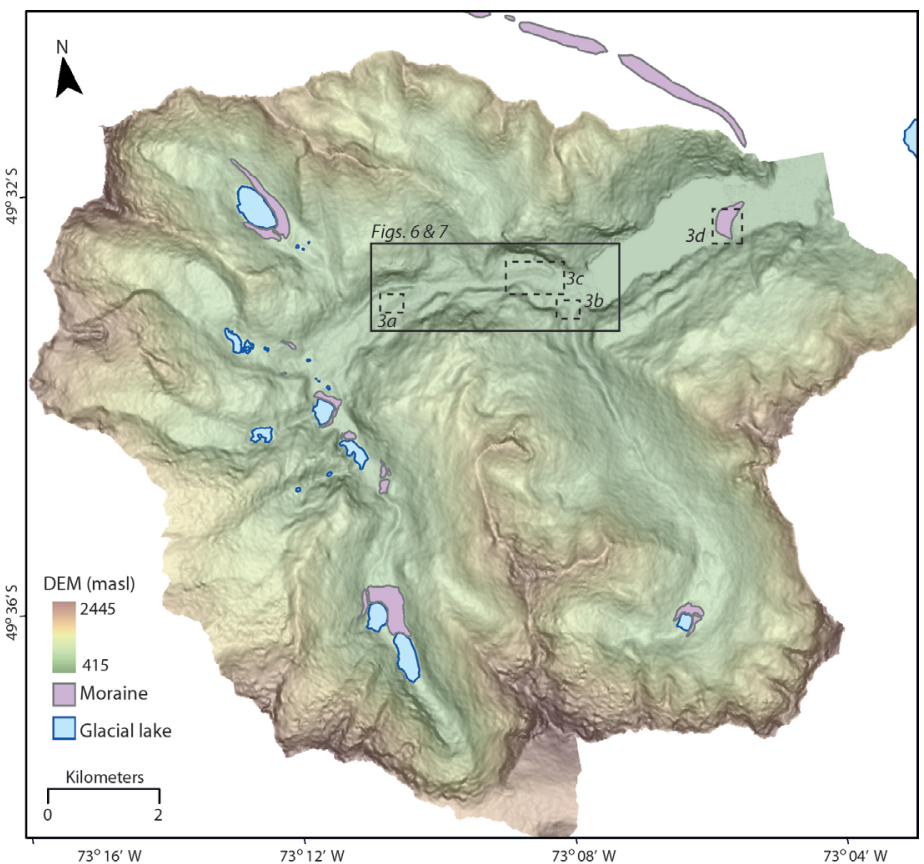

FIG. 2. ALOS PALSAR Digital Elevation Model with transparent greyscale slope DTM (darker/lighter shades represent steeper/ shallower slopes) showing the Laguna del Viedma catchment. The location of moraine complexes and glacial lakes upstream of the study reach in the valley are mapped. The moraines are inferred to date to Holocene neoglacial ice-margins showing an ice-free study reach from at least $4.0 \mathrm{ka}$. The locations of the satellite imagery in figure 3 , and the main terrace study area (Figs. 6, and Fig. 7) are shown. 
The drainage area of the Laguna del Viedma valley is $149 \mathrm{~km}^{2}$. The contemporary planform of the main valley floor is predominantly braided, and the three main rivers that feed the Laguna del Viedma are fed from glacial lakes (Fig. 2).

\section{Materials and methods}

\subsection{Geomorphological mapping}

Landform mapping was carried out at 1:5,000 scale using the high resolution ESRI base layer imagery (cf. Bendle et al., 2017a) in ArcMap 10.3 and ArcGIS Pro using UTM projection (Zone 18S). A selection of images are shown in figure 3. Recourse was made to the 3D imagery available in ArcGIS Earth to cross-check breaks of slope. Landform identification focused on glacial, fluvial and slope landforms where lack of forest cover allowed, and followed standard nomenclature used in geomorphological mapping in Patagonia (e.g., Bendle et al., 2017a, Leger et al., 2020). Standard GIS mapping protocols were used (Smith et al., 2014; Chandler et al., 2018).

\subsection{Satellite change detection}

To map the position of the Viedma Glacier ice margin and spatial extent of Laguna del Viedma, remote sensing imagery was used, with the timeframe spanning 1985 to 2019. Ice margins and lake extent were mapped manually, at 1:25,000 scale using ArcMap v.10.3, following standard GIS mapping protocols (e.g., Smith et al., 2014; Chandler et al., 2018). In total, 26 images were sourced from Landsat and Sentinel missions (Table 1), with a greater frequency of images in the latter part of the record. Eight of the 25 images had partial cloud cover (Table 1). Sometimes cloud cover precluded mapping the Viedma
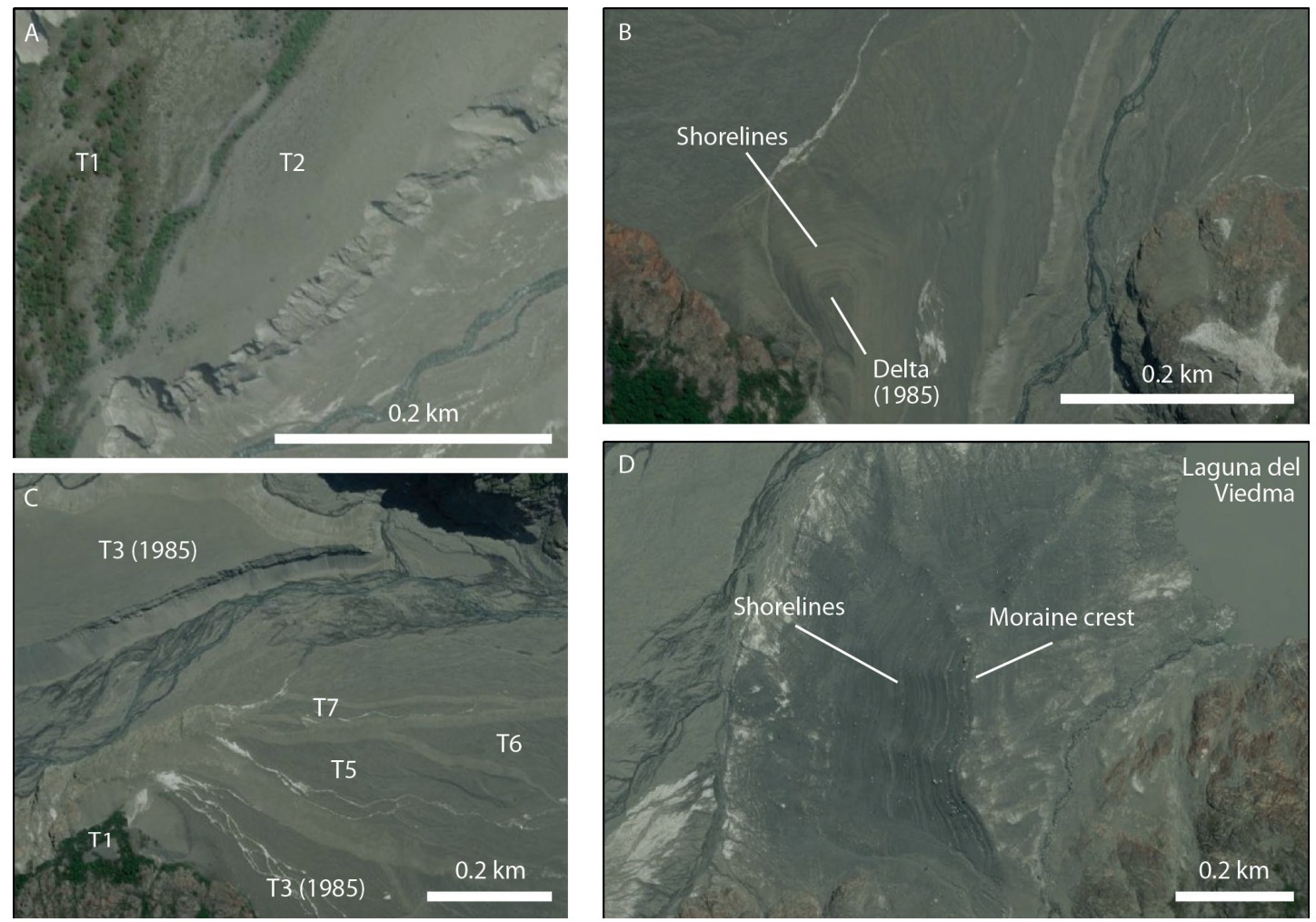

FIG. 3. Examples of the high resolution ESRI basemap satellite imagery used for the geomorphological mapping (cf. Bendle et al., 2017a). See figure 2 for locations. A. Example of the vegetated (T1) and unvegetated terraces; B. a delta and shorelines at the mouth of a tributary valley; C. a suite of terraces; and D. moraine crest with scattered boulders and shorelines. Note at high lake stands the moraine was submerged by Laguna del Viedma. Image sources: "Esri, Maxar, GeoEye, Earthstar Geographics, CNES/Airbus DS, USDA, USGS, AeroGRID, IGN and the GIS User Community”. 
TABLE 1. LIST OF THE SATELLITE DATA USED IN THE CHANGE DETECTION TIME SERIES. TICKS INDICATE CLOUD FREE CONDITIONS ABOVE LAGUNA DEL VIEDMA OR VIEDMA GLACIER, OTHERWISE PARTIAL CLOUD COVER IS INDICATED.

\begin{tabular}{|c|c|c|c|}
\hline Date & Satellite and Sensor & Laguna del Viedma & Viedma Glacier \\
\hline $27^{\text {th }}$ January 1985 & LM05 & $\checkmark$ & $\checkmark$ \\
\hline $27^{\text {th }}$ September 1986 & LT05 & $\checkmark$ & Tip of snout not covered \\
\hline $29^{\text {th }}$ October 1986 & LT05 & Partial cloud cover & $\checkmark$ \\
\hline $7^{\text {th }}$ March 1990 & LT05 & $\checkmark$ & $\checkmark$ \\
\hline $13^{\text {th }}$ February 1997 & LT05 & Partial cloud cover & Partial cloud cover \\
\hline 20 $0^{\text {th }}$ March 1998 & LT05 & $\checkmark$ & $\checkmark$ \\
\hline $12^{\text {th }}$ September 1998 & LT05 & $\checkmark$ & $\checkmark$ \\
\hline $7^{\text {th }}$ March 1999 & LT05 & Drainage event & $\checkmark$ \\
\hline $1^{\text {st }}$ October 1999 & LT05 & $\checkmark$ & $\checkmark$ \\
\hline $18^{\text {th }}$ November 1999 & LT05 & $\checkmark$ & $\checkmark$ \\
\hline $12^{\text {th }}$ March 2001 & LT05 & $\checkmark$ & $\checkmark$ \\
\hline $9^{\text {th }}$ December 2001 & LT05 & $\checkmark$ & $\checkmark$ \\
\hline $31^{\text {st }}$ March 2002 & LT05 & Partial cloud cover & $\checkmark$ \\
\hline $16^{\text {th }}$ January 2004 & LT05 & $\checkmark$ & $\checkmark$ \\
\hline $18^{\text {th }}$ January 2005 & LT05 & Partial cloud cover & Partial cloud cover \\
\hline $19^{\text {th }}$ February 2005 & LT05 & $\checkmark$ & $\checkmark$ \\
\hline $23^{\text {rd }}$ March 2005 & LT05 & $\checkmark$ & $\checkmark$ \\
\hline $6^{\text {th }}$ February 2006 & LT05 & $\checkmark$ & $\checkmark$ \\
\hline $2^{\text {nd }}$ September 2006 & LT05 & $\checkmark$ & $\checkmark$ \\
\hline $5^{\text {th }}$ September 2007 & LT05 & Partial cloud cover & Partial cloud cover \\
\hline $16^{\text {th }}$ January 2010 & LT05 & Partial cloud cover & Partial cloud cover \\
\hline $29^{\text {th }}$ September 2010 & LT05 & $\checkmark$ & $\checkmark$ \\
\hline $20^{\text {th }}$ February 2011 & LT05 & $\checkmark$ & $\checkmark$ \\
\hline $21^{\text {st January }} 2015$ & LT05 & $\checkmark$ & $\checkmark$ \\
\hline $18^{\text {th }}$ October 2016 & Sentinel-2 & $\checkmark$ & $\checkmark$ \\
\hline $7^{\text {th }}$ March 2019 & Sentinel-2 & $\checkmark$ & $\checkmark$ \\
\hline
\end{tabular}

$\mathbf{L}=$ Landsat; $\mathbf{M}=\mathrm{MSS} ; \mathbf{T}=\mathrm{TIRS}$ only; $\mathbf{0 5}=$ Landsat 5 .

glacier snout, but in all the selected images the spatial extent of Laguna del Viedma could be inferred. All the LANDSAT imagery was collected by the LANDSAT 5 TIR scanner, except for the January 1985 image, which used the MSS scanner.

\subsection{Terrace elevations}

Landform elevations were determined using the ALOS PALSAR Radiometric Terrain Correction dataset, a digital elevation model (DEM) product with a spatial resolution of $12.5 \mathrm{~m}$, considered more robust than the $30 \mathrm{~m}$ ASTER GDEM because more pixels covered the terrace remnants. A study evaluating vertical accuracy of open source DEMs for gully erosion concluded the root mean square error (RMSE) for the ALOS PALSAR data was $1.7 \mathrm{~m}$, compared to $1.9 \mathrm{~m}$ for the ASTER GDEM (Khal et al., 2020). The source DEM for the ALOS PALSAR dataset was the $30 \mathrm{~m}$ resolution SRTMGL1 DEM, collected in February 2000. To determine the relative heights of mapped terrace levels relative to the valley floor, elevations were extracted from mapped terrace surfaces and the median value for each was obtained. This was achieved by firstly mapping the terrace landform, then clipping the 
DEM to the landform shapefile, building the raster attribute table of the clipped raster, and then exporting the elevation data attributes. In addition, valley cross-sections were obtained in ArcGIS Pro using the Generate Points Along Line and Add Surface Information tools.

\section{Results}

\subsection{Glacial and lake geomorphology of the study area}

Prominent lateral moraines and a terminal moraine were mapped beyond the 1985 ice extent of the Viedma Glacier (Fig. 4). The terminal moraine, with arcuate ridges and kettle holes, forms an isthmus extending out into lago Viedma. This marks a position $2.5 \mathrm{~km}$ down-valley from the 1985 snout position and likely dates to the last Holocene readvance (neoglacial) dated to $\sim 0.53 \mathrm{ka}$ in the Fitz Roy valley to the north (Reynhout et al., 2019). At the time of moraine formation, the right margin of the Viedma glacier would have extended further into the Laguna del Viedma valley than at present, as indicated by the eroded bedrock beneath the treeline (Fig. 1), and a moraine to the west of the current ice margin. The satellite time series shows that this moraine was overtopped by lake waters during high stands of Laguna del Viedma and multiple, closely spaced, shorelines (formed by lake level falls) are imprinted upon it (Fig. 3D). This suggests the landform could have been reworked, but the orientation of the ridge and presence of large boulders indicate a moraine rather than fluvioglacial origin.

Up-valley from the Laguna del Viedma, tributary valleys contain prominent moraines (Fig. 2), with the youngest being unvegetated, while older moraine sets are covered in trees. This suggests multiple Holocene periods of glacier readvance (neoglacials). The geochronology of the Torres glacier moraines, preserved in the Fitz Roy valley to the north of the Viedma glacier, indicates Holocene glacier readvances at $9.7 \pm 0.4,6.9 \pm 0.2,6.1 \pm 0.3$, $4.5 \pm 0.2$ and $0.53 \pm 0.06 \mathrm{ka}$ (Reynhout et al., 2019). Only the youngest of the Fitz Roy valley moraines

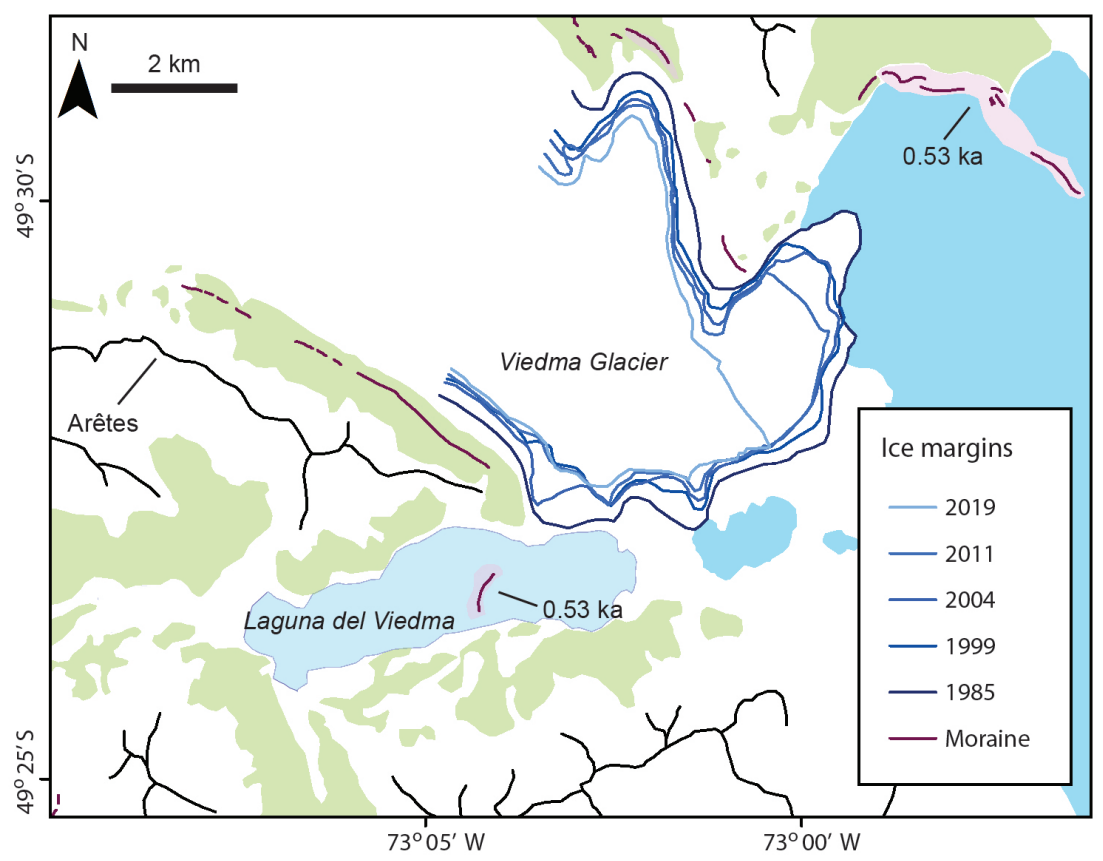

FIG. 4. Map of selected ice margin positions from satellite change detection analysis (1985-2019), with forest cover (green) indicating extent of postglacial soil development. Also shown are prominent Viedma Glacier moraines representing Late Holocene neoglacial ice limits, inferred as $0.53 \mathrm{ka}$ based on the Torres glacier record (Reynhout et al., 2019). The 1985 extent of Laguna del Viedma is shown. Note at this high lake level the mapped moraine would be submerged. 
is unvegetated. Moraines of the Upsala glacier (Lago Argentino basin) to the south of Laguna del Viedma record other neoglacials at 2.5-2.0 ka and 1.5-1.1 ka (Strelin et al., 2014). Kaplan et al. (2016), based on Holocene glacier reconstructions from the Lago Argentino basin, conclude that maximum Holocene glacier advances occurred 6.1 to $4.5 \mathrm{ka}$. The undated moraines (Fig. 2) are likely better correlated to those of the Torres rather than Upsala glacier because the narrower valley glacier landsystem of the Torres glacier is a more appropriate analogue than the large outlet Upsala glacier. Therefore, the youngest of the forested moraines in the Laguna del Viedma valley is correlated herein to the $4.5 \mathrm{ka}$ moraine (Kaplan et al., 2016; Reynhout et al., 2019), while it is highly likely the unvegetated moraines correlate to the final $(0.53 \mathrm{ka})$ neoglacial (Reynhout et al., 2019). Interpretation of the study area mapping and regional Holocene glacier chronology therefore indicates that a $7.6 \mathrm{~km}$ length of the Laguna del Viedma valley was likely ice-free between up-valley ice limits and the Viedma glacier moraine since at least 4.5-6.0 ka, allowing formation of Laguna del Viedma. The highest shorelines visible on satellite imagery indicate a maximum lake elevation of $\sim 530 \mathrm{~m}$ a.s.1.

\subsection{Change detection}

Glacier outlines for the lower Viedma glacier are shown in figure 4 for five snapshots from the satellite time series (1985-2019). The general pattern of change is for glacier snout recession from its 1985 extent to 2019 , but there is an acceleration in rate of recession over the last decade. The glacier receded $2.7 \mathrm{~km}$ from the inferred $0.53 \mathrm{ka}$ to 1860 terminal moraine position (Davies and Glasser, 2012; Reynhout et al., 2019) to its 1985 limit, at rates constrained to $5.2-21.6 \mathrm{~m} / \mathrm{yr}$. Between 1985 and 2011 ice receded at a rate of $100 \mathrm{~m} / \mathrm{yr}$, accelerating to $260 \mathrm{~m} / \mathrm{yr}$ over the period 2010 2019 , with $\sim 600 \mathrm{~m}$ of recession (not shown) in a single year (2015-2016). The ice margin position in the mouth of the Laguna del Viedma valley also receded, though here the greatest recession is from 1985 to 2004. Since 2004, this lateral ice margin has stabilised its position at the valley confluence.

The spatial extent of Laguna del Viedma is shown in figue 5 for selected years. In general, there is a decrease in the area of the lake from 1985 through to 2019 but there is evidence for cycles of emptying and refilling (lake regression/ transgression), as is usual for ice-dammed lakes

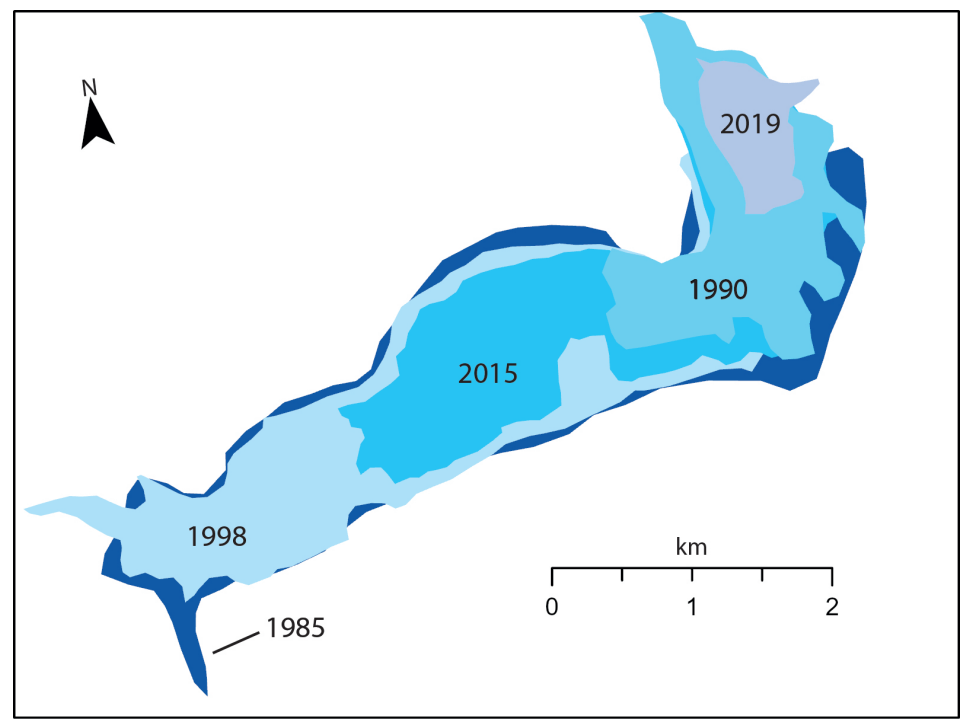

FIG. 5. Spatial extent of the Laguna del Viedma for selected dates from satellite change detection analysis (1985-2019): January 1985, March 1990, March 1998, January 2015 and March 2019. Note, the 2015 lake extent shows an example of a lake transgression, however, the main trend is for a falling lake level. 
in the Patagonian Andes (Dussaillant et al., 2010; Jacquet et al., 2017). Evident from the lake outlines is the effect of head-cutting erosion following lake drainage events (Jacquet et al., 2017), for example, an arm of the 1998 lake extends further up-valley than the 1985 shoreline position.

\subsection{Terraces of the Laguna del Viedma valley}

The geomorphological map of the Laguna del Viedma terraces is presented in figure 6 . The main river occupies a braidplain inset beneath a staircase of at least seven, distinguishable terrace surfaces. The highest $\mathrm{T} 1$ terrace is well-vegetated with trees and shrubs (Fig. 3A). The largest preserved area of T1 occurs in the west of the study area (Fig. 6) and occupies a position in between two rivers entering the lower Laguna del Viedma valley. Other preserved $\mathrm{T} 1$ surfaces occur on the southern valley side, where they are dissected by tributary streams entering the main valley. Where vegetation cover is sparser a braided channel pattern is visible on the terrace surface (Fig. 3A). Horseshoe-shaped scarp headwalls occur along the edges of the $\mathrm{T} 1$ terrace surfaces, indicating head-cutting erosion by mass movement events. The most easterly terrace remnant has a steeply dipping scarp slope, facing eastwards down-valley, characteristic of a delta.
The spatial extent of the unvegetated $\mathrm{T} 2$ terrace surface is less extensive than $\mathrm{T} 1$ and is represented by three preserved remnants all on the north side of the valley. The furthest eastwards terrace occupies a broadly similar position to the furthest eastwards T1 terrace remnant. Horseshoe-shaped scarp headwalls also occur along the edges of the T2 terrace surfaces (e.g., Fig. 3A). The T3 terrace extends further eastwards than $\mathrm{T} 1$ and $\mathrm{T} 2$, with two large terraces preserved on both the northern and southern sides of the valley (Fig. 3C), the easterly scarp slope of the latter is imprinted with shorelines. At the confluence with a southerly tributary a delta surface at the T3 level also preserves eroded shorelines (Fig. 3B). These terraces mark the position of the 1985 lake level (Fig. 5) at the beginning of the satellite time series. Smaller remnants of both T3 and T4 terrace levels occur up-valley, for example in the centre of the valley upstream from the confluence located at $73^{\circ} 9^{\prime} \mathrm{W}$ (Fig. 6). The T5-T7 terraces are all preserved at the eastern end of the study area (Fig. 6) and occur to the east of the 1985 and 1998 lake extents shown in figure 5 .

Selected valley cross-sections are shown in figure 7 and reconstructed long-profiles for terraces T1-T4 are presented in figure 8 . The highest terrace surface (T1) is located $40-70 \mathrm{~m}$ above the valley

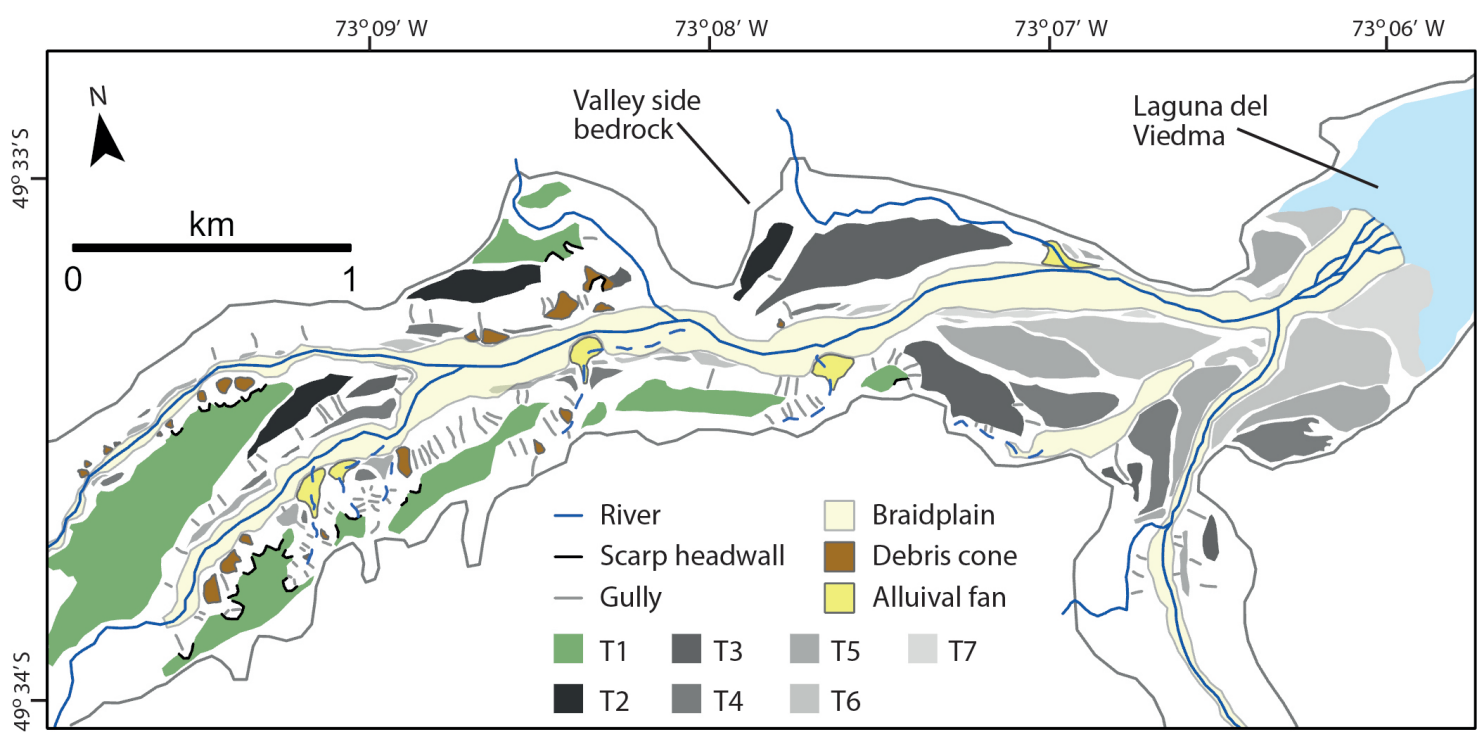

FIG. 6. Geomorphological map of the study reach in the Laguna del Viedma valley, showing the location of terraces (T1-T7) and other landforms. 

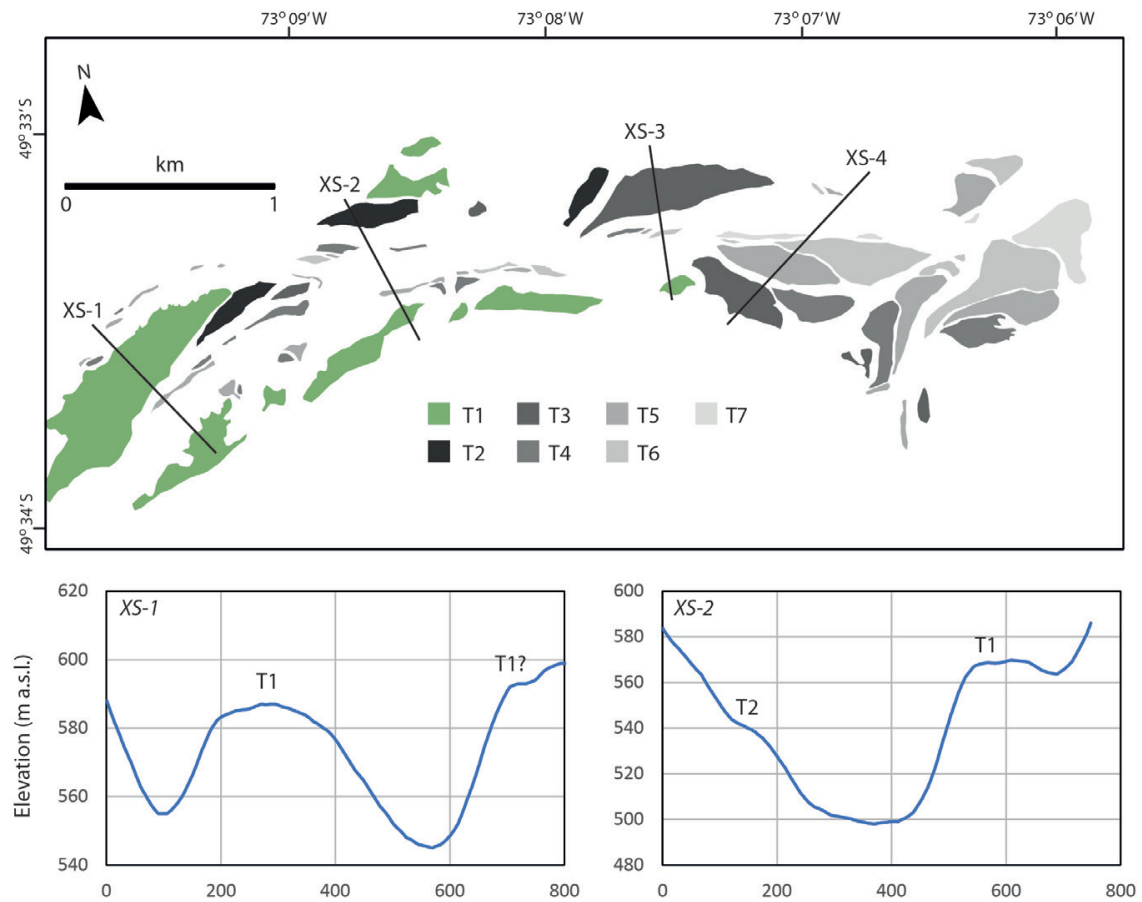

FIG. 7. Valley cross-sections extracted from the ALOS PALSAR DEM, with profile locations shown on the map in the upper panel, which illustrates terrace locations. Note in XS-1 there is the possibility of two vegetated terrace levels in the easternmost sector of the study area.

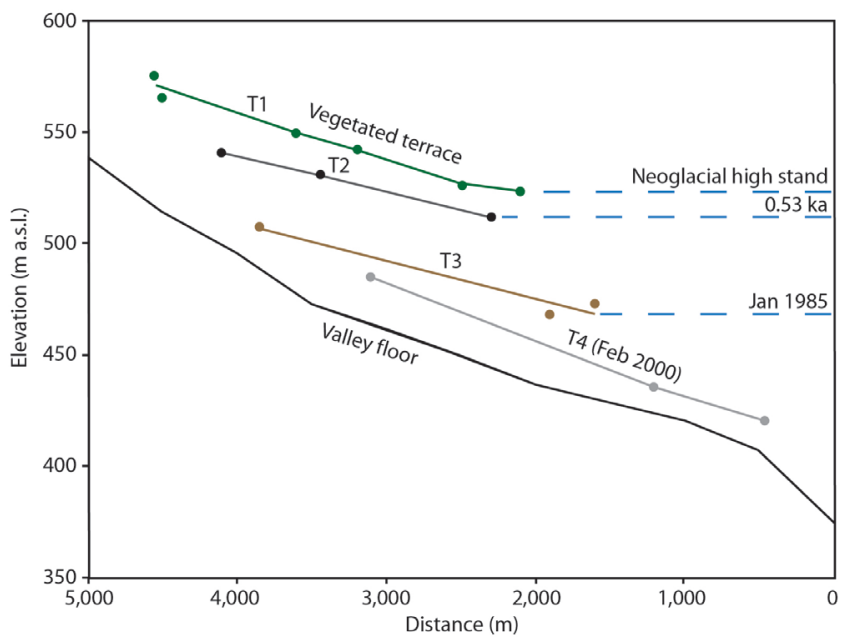

FIG. 8. Long profiles for terraces T1-T4 and the valley floor in February 2000, the time of the DEM used in the analysis. Circles represent the median elevation of, and mid-point distance along, mapped terrace remnants preserved in the valley. Note the T1 terrace is vegetated, the other more recent surfaces are unvegetated. 
floor, with the greatest height difference downvalley to the east as illustrated by cross-sections XS-1 to XS-3 (Fig. 7) and the terrace long-profile (Fig. 8). The average dimensionless slope of the terrace is calculated as 0.02 but appears to decrease down-valley where it grades to $\sim 520-530 \mathrm{~m}$ a.s.1., coinciding with the highest elevation shorelines in the valley.

Terrace T2 is located $\sim 10-20 \mathrm{~m}$ below T1, and the T3 surface, which grades to the 1985 lake level, is $\sim 30 \mathrm{~m}$ below T2. There is then a fall of $10 \mathrm{~m}$ (upstream) to $\sim 30 \mathrm{~m}$ (downstream) from terrace $\mathrm{T} 3$ to surface T4, the key incision event captured by the year 2000 elevation data and satellite record. The formation of terraces T5-T7 (Fig. 6) post-date the ALOS PALSAR DEM and so height differences were not calculated.

\section{Discussion}

\subsection{Rates of landscape change in the Laguna del Viedma valley}

The geomorphology of the Laguna del Viedma valley demonstrates incision of unconsolidated sediments on the valley floor with at least seven terrace surfaces identified through remote sensing, and a peak total incision of $\sim 70 \mathrm{~m}$ in a reach upstream of the 1985 delta position. Establishing the timeframe of this total incision, prior to the satellite time series is uncertain but given the geomorphological evidence - the position of the ice dammed lake and terraces below mature forest (Fig. 1) developed on post-glacial soils, the T1 floodplain would clearly have been active during Holocene neoglacials. One interpretation of the geomorphology is that the vegetated $\mathrm{T} 1$ terrace coincides with the vegetated moraines up-valley, while the unvegetated T2 terrace is associated with the youngest unvegetated moraines. As discussed in Section 4.1, based on the Torres glacier chronology the age of the youngest vegetated moraines are correlated to the $4.5 \mathrm{ka}$ neoglacial, while it is highly likely the unvegetated moraines date to the most recent $0.53 \mathrm{ka}$ neoglacial (Reynhout et al., 2019). Based on an age of 0.53 ka for the unvegetated moraines and terrace $\mathrm{T} 2$, an average incision rate of $\sim 0.08-0.12 \mathrm{~m} / \mathrm{yr}$ from $\mathrm{T} 2$ to the valley floor can be constrained.

The satellite imagery time series provides robust data on more recent rates of landscape change. In particular, the fall of $20 \mathrm{~m}$ from T3 (an active floodplain in 1985) to T4 prior to the source SRTM DEM data collection (2000) provides a minimum rate of incision of $1.33 \mathrm{~m} / \mathrm{yr}$. However, the satellite imagery (Fig. 9) indicates much of the incision occurred quickly. Fig. 9A shows the active floodplain at T3 feeding into Laguna del Viedma in January 1985. By September 1986 significant scarp slopes had already formed on the T3 terrace (Fig. 9B) and slumping of the scarp slope can be seen in the October 1986 image (Fig. 9C). Over the rest of the time series we can observe lateral erosion, in particular to the north of the river, likely due to lateral fluvial erosion coupled with mass movement processes. In terms of vertical incision, therefore, we can infer from the time series rapid incision in the order of metres to tens of metres immediately following lake level fall from its 1985 level. For comparison, Tobal et al. (2021) calculate an average incision rate for the río Deseado (46-470 S) outwash terraces of $\sim 0.135 \mathrm{~m} / \mathrm{ka}$ since 1.2 Ma in response to tectonic and climate forcing.

The impact of rapid base level falls on rates of incision has been demonstrated elsewhere through field, laboratory flume and remote sensing studies. The latter was employed by Jacquet et al. (2017) to quantify bed elevation changes following drainage of lago Cachet II, an ice dammed lake formed in a tributary valley of the Colonia glacier (Northern Patagonia Icefield). The study demonstrated that during a phase of 21 episodic GLOF drainage events since April 2008 there was a net loss of $\sim 25 \times 10^{6} \mathrm{~m}^{3}$ of sediment, with $>40 \mathrm{~m}$ of incision into the unconsolidated valley floor sediments.

Dam decommissioning projects also provide opportunities for investigating geomorphic response to rapid base level fall. Wilcox et al. (2014) monitored the removal of Condit Dam on the White Salmon River in northwest USA. The $38 \mathrm{~m}$ high dam, which impounded 1.6 million $\mathrm{m}^{3}$ of water, was breached by blasting a $5 \mathrm{~m}$ hole in its base. Following the breach, the reservoir drained in 90 minutes and $\sim 10 \%$ of its 1.8 million $\mathrm{m}^{3}$ of sediment was eroded during this initial phase of the event. Sediment mobilisation included slumping of the reservoir sediments, which helped contribute to hyperconcentrated flows downstream. Erosion of the reservoir sediments proceeded over weeks to months, and by week 15 it was calculated that $>60 \%$ of reservoir sediment had been eroded (Wilcox et al., 2014).

Laboratory flume experiments have been used to investigate the geomorphic processes of rapid base level falls. Experiments were carried out by Cantelli 

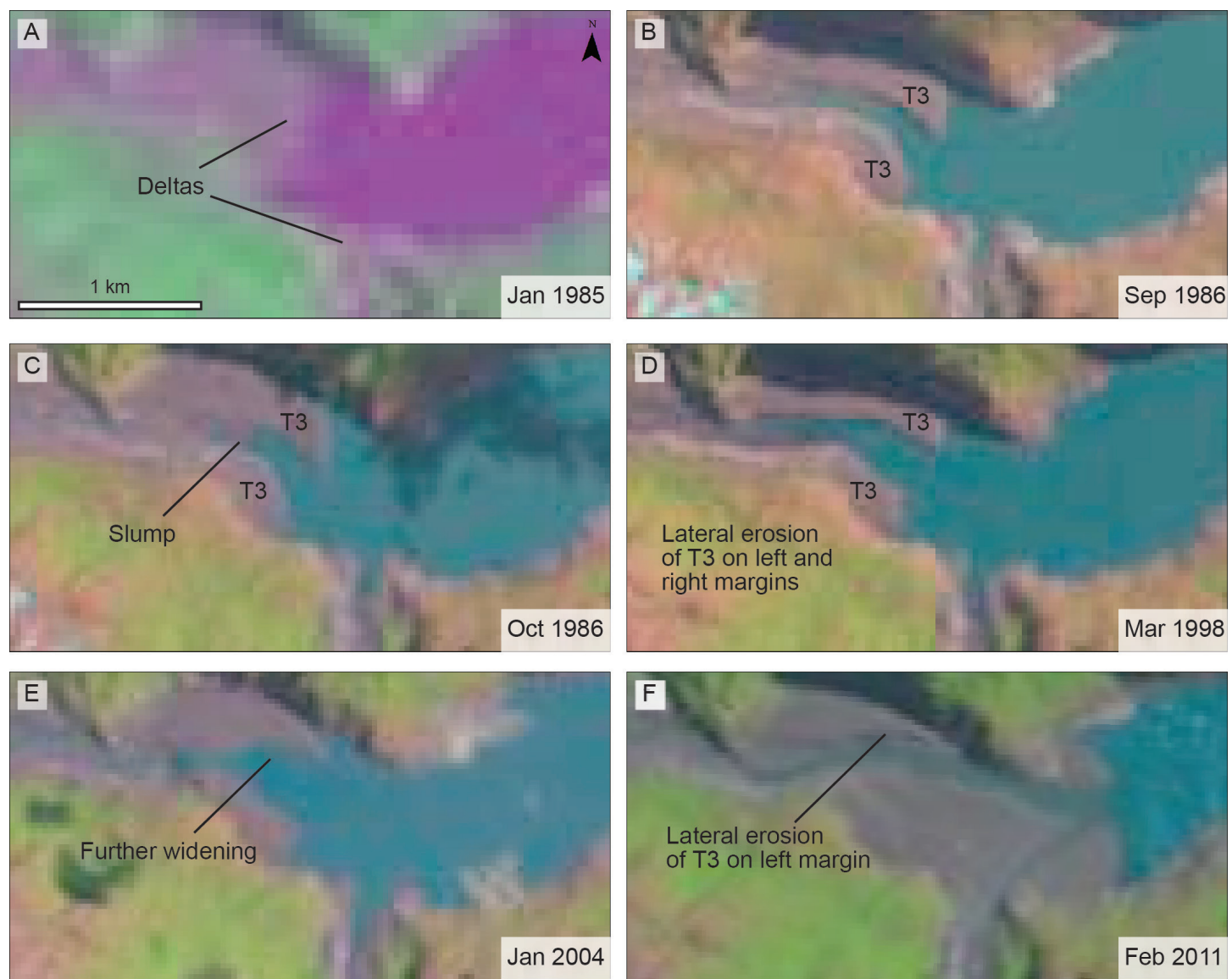

FIG. 9. Selected LANDSAT imagery from the time series, showing a sector focused on the up-valley limit of the Laguna del Viedma in 1985. Key landforms and geomorphic processes are indicated.

et al. (2004) to investigate the geomorphological impact of dam removal. During an experimental run with complete dam removal, Cantelli et al. (2004) observed erosional narrowing, which resulted in initially high sediment discharges. Due to maximum boundary shear stresses in the middle of the channel, reducing to zero at the channel margins, incision rates were greatest in the centre promoting vertical downcutting and narrowing of the channel. This created a positive feedback where streamlines were focused towards the centre of the channel increasing erosion rates. Channel narrowing ceased when lateral sediment transport, from the increasingly higher banks, slowed channel degradation. Once degradation was stopped the channel widened (Cantelli et al., 2004).

In summary, therefore, the available DEM and satellite time series from Laguna del Viedma demonstrates rapid vertical incision from $\mathrm{T} 3$ to $\mathrm{T} 4$ with subsequent valley floor widening, consistent with observations from other ice dammed lake drainage events (e.g., Jacquet et al., 2017), and both field and flume dam removal students (Cantelli et al., 2004; Wilcox et al., 2014).

\subsection{Implications for Late Quaternary landscape evolution}

The Laguna del Viedma and Cachet valleys, dammed by outlet glaciers of the Southern and Northern Patagonia icefields respectively, can be considered modern analogues for landscapes of deglaciation in the Patagonian Andes. Late Quaternary deglaciation of Patagonia featured large outlet glaciers, which had the potential to dam tributary valleys. Glacier recession led to the formation of large proglacial lakes (Caldenius, 1932; Turner et al., 2005; Hein et al., 2010; Solari et al., 2012; García et al., 2014, 
2019; Thorndycraft et al., 2019), most of which either totally drained e.g., the Cisnes valley (García et al., 2019), or partially drained by punctuated drainage events e.g., lago General Carrera/Buenos Aires (Bell, 2008). These lake falls were in the order of 10 s to 100 s of metres and the largest could have caused catastrophic flooding, as demonstrated by the 110,000 $\mathrm{m}^{3} / \mathrm{s}$ flood reconstructed in the Baker valley (Benito and Thorndycraft, 2020). Across Patagonia, therefore, there was a spatially and temporally complex pattern of lake drainage events (Thorndycraft et al., 2019), which resulted in rapid base level lowering leading to the style of landscape evolution recorded in the Laguna del Viedma valley.

Examples of Late Quaternary paraglacial landscapes (Ballantyne, 2002) from $46-47^{\circ} \mathrm{S}$ in Patagonia (Fig. 10), with significant valley incision, are presented in figures 11 and 12. The terrace sequence of the Río
Jeinimeni valley (Fig. 11A) exhibits up to $\sim 100 \mathrm{~m}$ of total incision in the reach photographed. At the 25 and $20 \mathrm{ka}$ timeframes of the PATICE reconstruction of the former Patagonian Ice Sheet, Davies et al. (2020) show the valley to be ice free and therefore the valley has a similar geomorphic setting to the Laguna del Viedma, with a large outlet glacier blocking an ice-free river draining glaciated valleys (Fig. 10). Drainage from the Jeinimeni valley would have been blocked (creating an ice dammed lake) by the Buenos Aires ice lobe, the snout of which was located $\sim 40 \mathrm{~km}$ to the east of the valley mouth until at least $17 \mathrm{ka}$ (Bendle et al., 2017b). The landscape history of the palaeolake is yet to be detailed but the terrace sequence (Fig. 9a), based on the observed record from Laguna del Viedma, likely records a series of rapid incisions in response to lake level falls as the Buenos Aires ice-lobe thinned and receded.

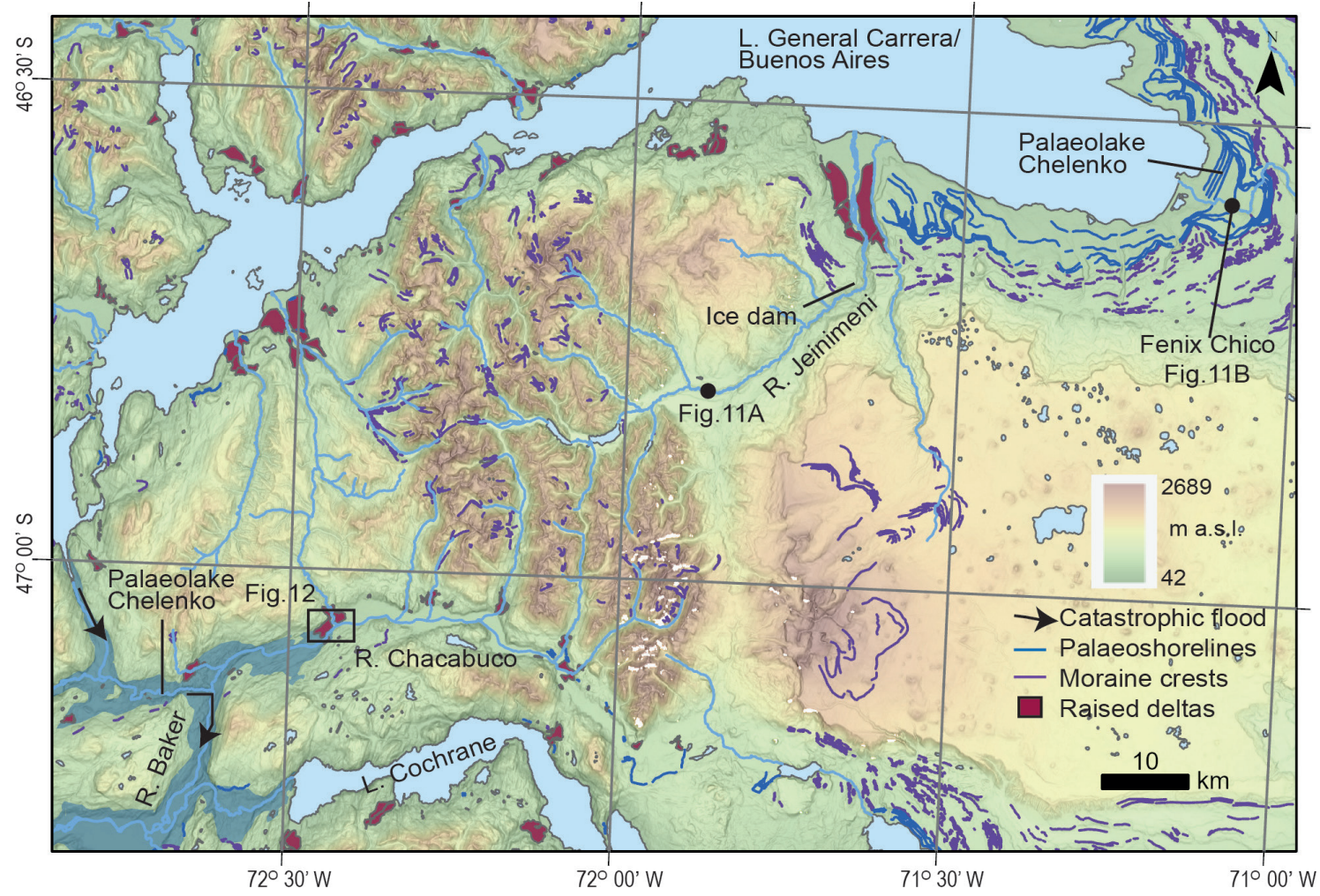

FIG. 10. Map showing the geomorphological context of the valleys discussed in Section 5.2, with selected landforms from Bendle et al. (2017a). Lateral moraine crests mark the likely position of the Jeinimeni ice dam. Palaeolake shorelines show that the Fénix Chico valley was developed following lake level falls, the first constrained to 14.2-12.6 ka (Thorndycraft et al., 2019). The valley floor at the Chacabuco site (Fig. 12) was influenced by two base level falls: 1) 11.7-12.6 ka: the drainage of lago Chelenko (Thorndycraft et al., 2019), a large palaeolake that joined lago General Carrera/Buenos Aires with lago Cochrane/ Puerreydon through the Baker valley (grey-blue shading); and 2) 9.6 $\pm 0.8 \mathrm{ka}$ : the Bertrand-Baker catastrophic flood (Benito and Thorndycraft, 2020; Benito et al., 2021), which eroded bedrock along the indicated flow pathways. 
The río Fénix Chico provides an example of a valley formed in a proglacial geomorphic setting (Fig. 10). The development of a proglacial lake at $\sim 400 \mathrm{~m}$ a.s.l. at this locality occurred from $\sim 18.0 \mathrm{ka}$ (Bendle et al., 2017b). The geomorphological evidence of deltas and palaeoshorelines around present day lago General Carrera/Bueno Aires (Fig. 10) demonstrate a lake level fall of $\sim 100 \mathrm{~m}$ (e.g., Bell, 2008), triggered by a drainage reversal from Atlantic to Pacific drainage (Turner et al., 2005), with timing constrained to 14.2$12.6 \mathrm{ka}$ by Thorndycraft et al. (2019). Here, vertical incision following the lake level fall likely created instability in the saturated lacustrine sediments so the Fénix Chico landscape is dominated by mass movement processes (Fig. 11b), rather than fluvial terrace formation, as also documented at lago Puerreydón to the South (Pánek et al., 2020). The drainage reversal event led to the rapid formation of the Fénix Chico valley, which contrasts with the Laguna del Viedma setting, where catchment drainage has fed into the lake up-valley for millennia since ice-free conditions were established.

The final example, presented in figure 12 , is from the Chacabuco valley in Chile, where there is evidence for multiple drivers of incision. The altitude of raised deltas (Fig. 12), 40-50 m higher than equivalent landforms further east, demonstrate isostatic uplift (see Fig. 10 in Thorndycraft et al., 2019). The valley floor delta flowed into Palaeolake Chelenko, which drained 12.6-11.7 ka (Thorndycraft et al., 2019). Furthermore, the catastrophic flood of the río Baker (see Fig. 10 for the flood pathway), which occurred $\sim 9.6 \pm 0.8 \mathrm{ka}$ (Benito et al., 2021), triggered geologically instantaneous bedrock incision of $\sim 20 \mathrm{~m}$ downstream at the Baker-Chacabuco confluence (Benito and Thorndycraft, 2020). Maximum total incision at the site reaches $\sim 90 \mathrm{~m}$, consistent with the evidence from the modern Laguna del Viedma and Cachet II (Jacquet et al., 2017) lakes, and approximately double the constrained isostatic uplift
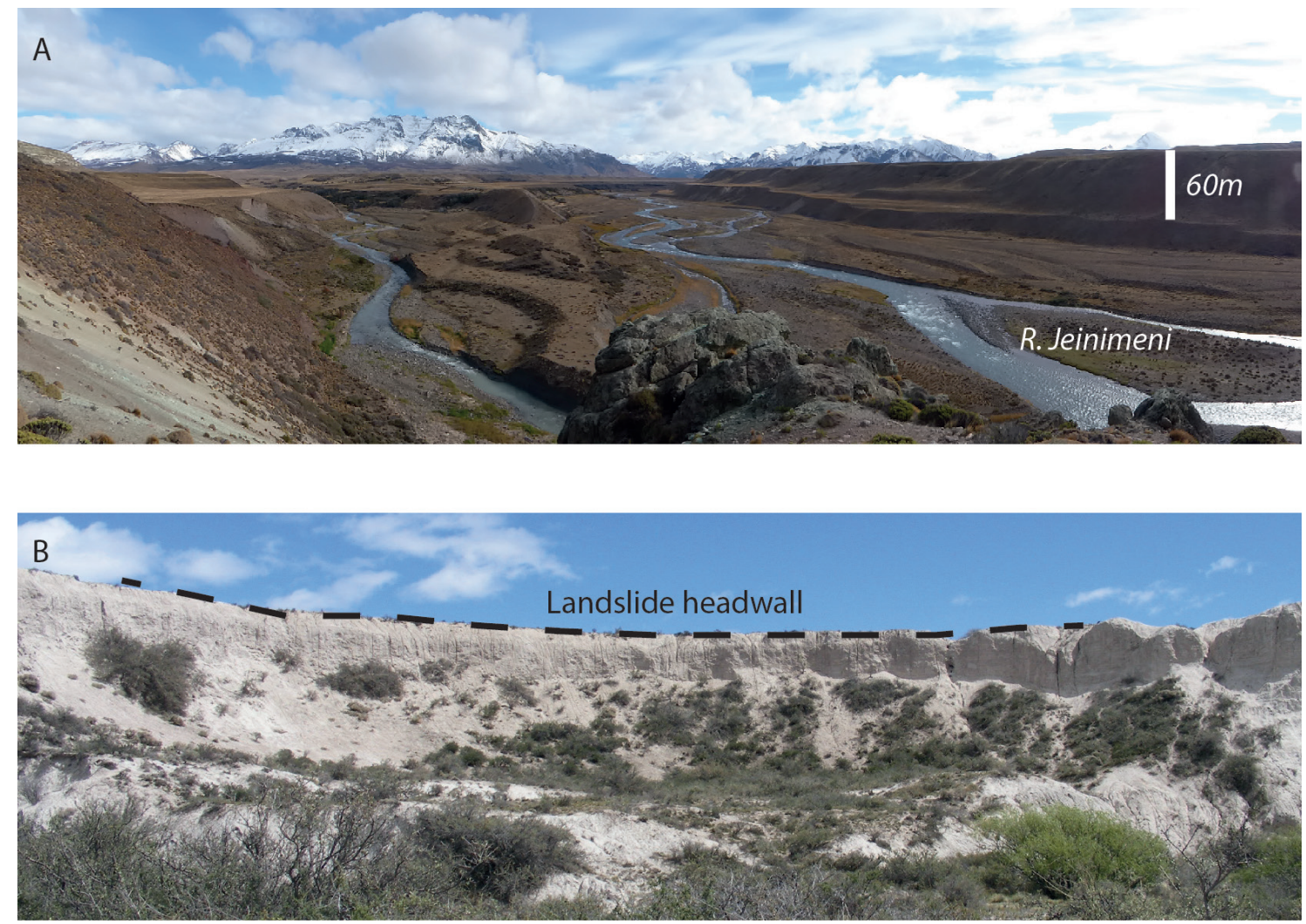

FIG. 11. Examples of Late Quaternary valleys featuring incision caused by lake level fall (see Fig. 1 for locations): A. River terrace sequence of the Río Jeinimeni valley (Argentina/Chile); and B. landslide in lacustrine sediments on the north side of the Fénix Chico valley (Argentina). 


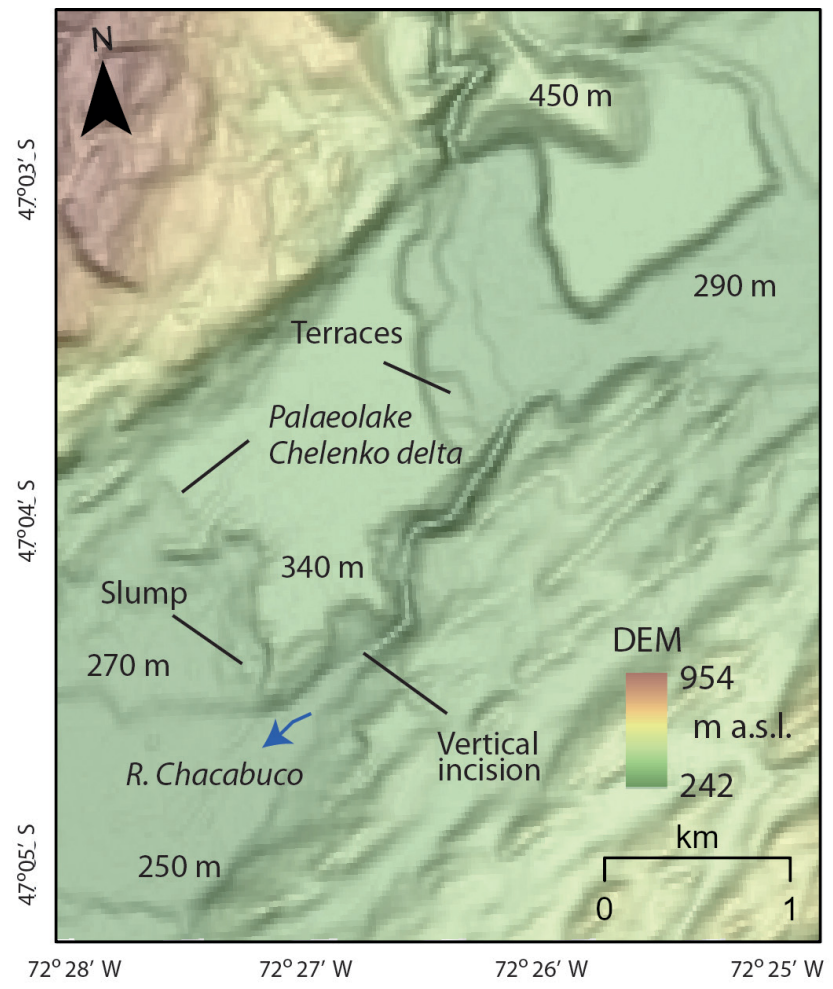

FIG. 12. ALOS PALSAR DEM with transparent greyscale slope DTM overlay from the Chacabuco valley, Chile (see Fig. 1 for locations), illustrating a delta which fed into Palaeolake Chelenko (Thorndycraft et al., 2019) and river terrace sequence. Some key spot heights (m a.s.1.) are added to help demonstrate the amount of incision. at this locality. The vertical incision downstream of the terraced tributary valley (Fig. 12) is consistent with rapid vertical incision of the Cantelli et al. (2004) flume experiments, however the terraces in the lower reach of the tributary valley could be a complex response to both rapid base level fall and isostatic uplift. The Chacabuco valley, therefore, has experienced a range of spatially variable rates of isostatic uplift as well as rapid base level falls.

It is challenging to date Late Quaternary rapid incision events as the centennial, at best, uncertainty ranges on typical dates from fluvial terraces are larger than the decadal/sub-decadal timescales it took to form the Laguna del Viedma terraces. However, careful spatial and temporal analyses of landform records in the Patagonian Andes may yield insights to decipher likely controls (e.g., isostatic uplift versus base level fall) and relative rates of landscape incision (e.g., rapid versus centennial/millennial scales).

\section{Conclusions}

Satellite time series (1985-2019) and geomorphological mapping of the Laguna del Viedma valley $\left(49^{\circ} \mathrm{S}\right)$, dammed by the Viedma glacier, demonstrates rapid terrace formation in response to lake level falls in the order of tens of metres. The available DEM shows that the formation of the $\sim 20 \mathrm{~m} \mathrm{~T} 3$ terrace level occurred at a mean rate of $1.33 \mathrm{~m} / \mathrm{yr}$ over a $\sim 15$ year time period, but the satellite evidence shows that most of the incision likely occurred more rapidly based on the apparent size of the scarp slope evident within months of the drainage event on satellite imagery.

The data have implications for the interpretation of rates of landscape evolution based on Late Quaternary landform records of the Patagonian Andes during the Late Glacial Interglacial Transition, given the widespread occurrence of palaeolake drainage events across the region. Examples of landscapes from the río Baker catchment $\left(45-46^{\circ} \mathrm{S}\right)$, which we know to have been affected by rapid base level falls (e.g., Thorndycraft et al., 2019; Benito and Thorndycraft, 2020) were presented to demonstrate that sudden base level falls likely played an important role in landscape incision processes in addition to geophysical drivers of uplift such as isostatic uplift or neotectonics.

\section{Acknowledgements}

I used part of the satellite time series for teaching resources I developed for an undergraduate remote 
sensing and GIS class, so I thank students who took the course and contributed to discussions of the data. My thoughts on Late Quaternary landscape evolution in Patagonia have benefitted from discussions in the field with numerous colleagues and postgraduate students including: J. Bendle, G. Benito, E. Cooper, B. Davies, J.L. García, J. Martin, A. Nuevo-Delaunay, C. Méndez, A. Palmer, J. Pike and C. Sancho. I thank two anonymous reviewers whose comments improved the original manuscript.

\section{References}

Ávila, P.; Dávila, F.M. 2019. Lithospheric thinning and dynamic uplift effects during slab window formation, southern Patagonia $\left(45^{\circ}-55^{\circ} \mathrm{S}\right)$. Journal of Geodynamics 133 (101689): doi: 10.1016/j.jog.2019.101689.

Baker, V.R. 2009. The Channeled Scabland: A retrospective. Annual Review of Earth and Planetary Sciences 37: 393-411. doi: 10.1016/j.earscirev.2020.103379.

Ballantyne, C.K. 2002. Paraglacial geomorphology. Quaternary Science Reviews 21: 1935-2017.

Bendle, J.M.; Thorndycraft, V.R.; Palmer, A.P. 2017a. The glacial geomorphology of the Lago Buenos Aires and Lago Pueyrredón ice lobes of central Patagonia. Journal of Maps 13: 654-673.

Bendle, J.M.; Palmer, A.P.; Thorndycraft, V.R.; Matthews, I.P. 2017b. High-resolution chronology for deglaciation of the Patagonian Ice Sheet at Lago Buenos Aires $\left(46.5^{\circ} \mathrm{S}\right)$ revealed through varve chronology and Bayesian age modelling. Quaternary Science Reviews 177: 314-339.

Benito, G.; Thorndycraft, V.R. 2020. Catastrophic glacial-lake outburst flooding of the Patagonian Ice Sheet. Earth-Science Reviews 200 (102996): 22 p. doi: 10.1016/j.earscirev.2019.102996.

Benito, G.; Thorneycroft, V.R.; Medialdea, A.; Machado, M.J.; Sancho, C.; Dussaillant, A. 2021. Declining discharge of glacier outburst floods through the Holocene in central Patagonia. Quaternary Science Reviews 256, 106810: 23 p. doi: 10.1016/j. quascirev.2021.106810.

Bell, C. 2008. Punctuated drainage of an ice-dammed quaternary lake in southern South America. Geografiska Annaller Series A, Physical Geography 90 (1): 1-17. doi: 10.1111/j.1468-0459.2008.00330.x.

Bowman, D.; Svoray, T; Devora, Sh.; Shapira, I.; Laronne, J.B. 2010. Extreme rates of channel incision and shape evolution in response to a continuous, rapid base-level fall, the Dead Sea, Israel. Geomorphology 114: 227-237.

Caldenius, C. 1932. Las glaciaciones cuaternarias en la Patagonia y Tierra del Fuego. Geografiska Annaler 14: 1-164. doi: 10.1080/20014422.1932.11880545.
Cantelli, A.; Paola, C.; Parker, G. 2004. Experiments on upstream migrating erosional narrowing and widening of an incisional channel caused by dam removal. Water Resources Research 40: 1-12.

Chandler, B.; Lovell, H.; Boston, C.; Lukas, S.; Barr, I.; Benediktsson, Í.; Benn, D.; Clark, C.; Darvill, C.; Evans, D.; Ewertowski, M.; Loibl, D.; Margold, M.; Otto, J-C.; Roberts, D.; Stokes, C.; Storrar, R.; Stroeven, A. 2018. Glacial geomorphological mapping: A review of approaches and frameworks for best practice. EarthScience Reviews 185: 806-846.

Dávila, F.M.; Ávila, P.; Martina, F. 2019. Relative contributions of tectonics and dynamic topography to the Mesozoic-Cenozoic subsidence of southern Patagonia. Journal of South American Earth Sciences 93: 412-423.

Davis, W.M. 1902. Base-level, grade, and peneplain. Journal of Geology 10: 77-111.

Davies, B.; Glasser, N. 2012. Accelerating shrinkage of Patagonian glaciers from the Little Ice Age ( AD 1870 ) to 2011. Journal of Glaciology 58: 1063-108.

Davies, B.J.; Darvill, C.M.; Lovell, H.; Bendle, J.M.; Dowdeswell, J.A.; Fabel, D.; García, J-L.; Geiger, A.; Glasser, N.F.; Gheorgiu, D.M.; Harrison, S.; Hein, A.S.; Kaplan, M.R.; Martin, J.; Mendelova, M.; Palmer, A.P.; Pelto, M.; Rodés, Á.; Sagredo, E.A.; Smedley, R.; Smellie, J.; Thorndycraft, V.R.; Wolff, I. 2020. The evolution of the Patagonian Ice Sheet from $35 \mathrm{ka}$ to the Present Day (PATICE). Earth-Science Reviews 204 (103152): 77 p. doi: 10.1016/j.earscirev.2020.103152.

Dietrich, R.; Ivins, E.R.; Casassa, G.; Lange, H.; Wendt, J.; Fritsche, M. 2010. Rapid crustal uplift in Patagonia due to enhanced ice loss. Earth and Planetary Science Letters 289: 22-29.

Dussaillant, A.; Benito, G.; Buytaert, W.; Carling, P.; Meier, C.; Espinoza, F. 2010. Repeated glacial lake outburst floods in Patagonia: An increasing hazard? Natural Hazards 54: 469-481.

Faulkner, D.J.; Larson, P.H.; Jol, H.M.; Running, G.L.; Loope, H.M.; Goble, R.J. 2016. Autogenic incision and terrace formation resulting from abrupt late-glacial base-level fall, lower Chippewa River, Wisconsin, USA. Geomorphology 266: 75-95.

García, J-L.; Hall, B.L.; Kaplan, M.R.; Rodrigo M.; Vega, R.M.; Strelin, J.A. 2014. Glacial geomorphology of the Torres del Paine region (southern Patagonia): Implications for glaciation, deglaciation and paleolake history. Geomorphology 204: 599-616.

García, J-L.; Maldonado, A.; de Porras, M.E; Delaunay, A.; Reyes, O.; Ebensperger, C.; Binnie, S.; Lüthgens, C.; Méndez, C. 2019. Early deglaciation and paleolake history of the Río Cisnes Glacier, Patagonian Ice Sheet (44º S). Quaternary Research 91: 194-217. 
Guillaume, B.; Gautheron, C.; Simon-Labric, T.; Martinod, J.; Rodda, M.; Douvill, E. 2013. Dynamic topography control on Patagonian relief evolution as inferred from low temperature thermochronology. Earth and Planetary Science Letters 364: 157-167.

Harvey, A.M. 2002. The role of base-level change in the dissection of alluvial fans: case studies from southeast Spain and Nevada. Geomorphology 45: 67-87.

Hein, A.S.; Hulton, N.R.J.; Dunai, T.J.; Sugden, D.E.; Kaplan, M.R.; Xu, S. 2010. The chronology of the Last Glacial Maximum and deglacial events in central Argentine Patagonia. Quaternary Science Reviews 29: 1212-1227.

Jacquet, J.; McCoy, S.W.; McGrath, D.; Nimick, D.A.; Fahey, M.; O'kuinghttons, J.; Friesen, B.A.; Leidich, J. 2017. Hydrologic and geomorphic changes resulting from episodic glacial lake outburst floods: Río Colonia, Patagonia, Chile. Geophysical Research Letters 44: 854-864.

Kaplan, M.R.; Schaefer, J.M.; Strelin, J.A.; Denton, G.H.; Anderson, R.F.; Vandergoes, M.J.; Finkel, R.C.; Schwartze, R.; Travis, S.G.; García, J.L.; Martini, M.A.; Nielsen, S.H.H. 2016. Patagonian and southern South Atlantic view of Holocene climate. Quaternary Science Reviews 141: 112-125.

Khal, M.; Algouti, A.; Algouti, A.; Akdim, N.; Stankevich, S.A.; Menenti, M. 2020. Evaluation of open Digital Elevation Models: estimation of topographic indices relevant to erosion risk in the Wadi M'Goun watershed, Morocco Maryam. AIMS Geosciences 6: 231-257.

Leger, T.; Hein, A.; Bingham, R.; Martini, M.; Soteres, R.; Sagredo, E.; Martínez, O. 2020. The glacial geomorphology of the Río Corcovado, Río Huemul and Lago Palena/General Vintter valleys, northeastern Patagonia $\left(43^{\circ} \mathrm{S}, 71^{\circ} \mathrm{W}\right)$. Journal of Maps 16: 651-668.

O'Connor, J.E.; Baker, V.R.; Waitt, R.B.; Smith, L.N.; Cannon, C.M.; George, D.L.; Denlinger, R.P. 2020. The Missoula and Bonneville floods -a review of ice-age megafloods in the Columbia River basin. Earth-Science Reviews 208 (103181): 53 p. doi: 10.1016/j.earscirev.2020.103181.

Pánek, T.; Břežný, M.; Kilnar, B.; Winocur, D. 2021. Complex causes of landslides after ice sheet retreat: Post-LGM mass movements in the Northern Patagonian Icefield region. Science of the Total Environment 758 (143684): 17 p. doi: 10.1016/j.scitotenv.2020.143684.
Ponce, J.F.; Guillot, M.G.; Balocchi, L.D.; Martínez, O. 2019. Geomorphological evidences of paleosurge activity in Lake Viedma Lobe, Patagonia, Argentina. Geomorphology 327: 511-522.

Reynhout, S.A.; Sagredo, E.A.; Kaplan, M.R.; Aravena, J.C.; Martin, M.A.; Moreno, P.I.; Rojas, M.; Schwartz, R.; Schaefer, J.M. 2019. Holocene glacier fluctuations in Patagonia are modulated by summer insolation intensity and paced by Southern Annular Mode-like variability. Quaternary Science Reviews 220: 178-187.

Schumm, S.A. 1993. River response to baselevel change: Implications for sequence stratigraphy. Journal of Geology 101: 279-294.

Smith, M.J.; Paron, P.; Griffiths, J.S. 2011. Geomorphological Mapping: Methods and Applications. Developments in Earth Surface Processes 15. Elsevier: 610 p. Amsterdam.

Solari, M.A.; Le Roux, J.P.; Hervé, F.; Airo, A.; Calderón, M. 2012. Evolution of the Great Tehuleche Palaeolake in the Torres del Paine National Park of Chilean Patagonia during the Last Glacial Maximum and Holocene. Andean Geology 39: 1-21. doi: 10.5027/andgeoV39N1-a01.

Strelin, J.A.; Kaplan, M.R.; Vandergoes, M.J.; Denton, G.H.; Schaefer, J.M. 2014. Holocene glacier history of the Lago Argentino basin, Southern Patagonian Icefield. Quaternary Science Reviews 101: 124-145. Thorndycraft, V.R.; Bendle, J.M.; Benito, G.; Davies, B.J.; Sancho, C.; Palmer, A.P.; Fabel, D.; Medialdea, A.; Martin, J.R.V. 2019. Glacial lake evolution and AtlanticPacific drainage reversals during deglaciation of the Patagonian Ice Sheet. Quaternary Science Reviews 203: 102-127.

Tobal, J.E.; García Morabito, E.; Terrizzano, C.M.; Zech, R.; Colavitto, B.; Struck, J.; Christl, M.; Ghiglione, M.C. 2021. Quaternary landscape evolution of patagonia at the Chilean Triple Junction: Climate and tectonic forcings. Quaternary Science Reviews 261 (106960). 17 p. doi: 10.1016/j.quascirev.2021.106960.

Turner, K.; Fogwill, C.; McCullock, R.; Sugden, D. 2005. Deglaciation of the eastern flank of the North Patagonian Icefield and associated continental-scale lake diversions. Geografiska Annaller 87: 363-374.

Wilcox, A.C.; O’Connor, J.E.; Major, J.J. 2014. Rapid reservoir erosion, hyperconcentrated flow, and downstream deposition triggered by breaching of $38 \mathrm{~m}$ tall Condit Dam, White Salmon River, Washington. Journal of Geophysical Research Earth Surface 119: 1376-1394.

Manuscript received: July 30, 2021; revised/accepted: October 22, 2021; available online: January 31, 2022. 